Atmos. Meas. Tech. Discuss., https://doi.org/10.5194/amt-2018-45

16 Science \& Technology, Nanjing 210044, China

17 Tel.: $+86-18251919852$

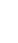
2

Corresponding authors: Drs. Jun Zheng and Yan Ma

Email: zheng.jun@nuist.edu.cn and mayan@nuist.edu.cn

\author{
16 Science \& Technology, Nanjing 210044, China
}

17.2. Tel: $+86-18251919852$

18 Fax: $+86-25-58731090$

\title{
Sensitivity of a Q-ACSM to chamber generated SOA with different oxidation states
}

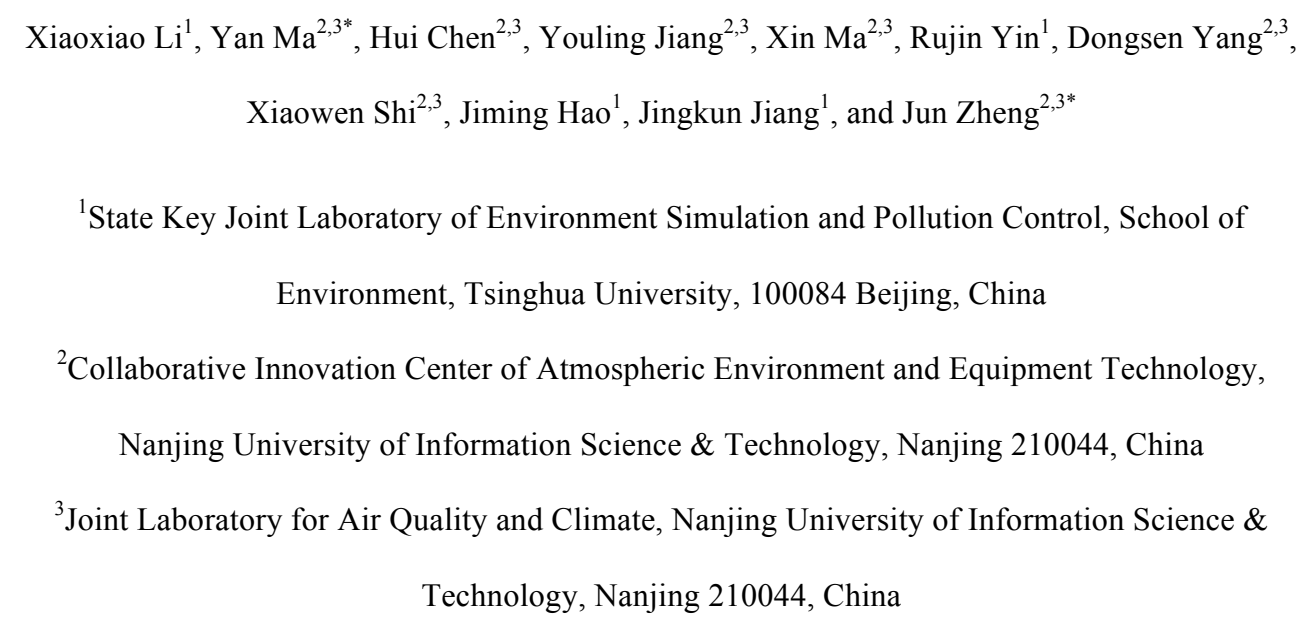
Xiaowen $\mathrm{Shi}^{2,3}$, Jiming $\mathrm{Hao}^{1}$, Jingkun Jiang ${ }^{1}$, and Jun Zheng ${ }^{2,3^{*}}$ ${ }^{1}$ State Key Joint Laboratory of Environment Simulation and Pollution Control, School of ${ }^{2}$ Collaborative Innovation Center of Atmospheric Environment and Equipment Technology, Nanjing University of Information Science \& Technology, Nanjing 210044, China ${ }^{3}$ Joint Laboratory for Air Quality and Climate, Nanjing University of Information Science \& Technology, Nanjing 210044, China

5 Address: School of Environmental Science and Engineering, Nanjing University of Information

\section{Abstract}

20 The accuracy in quantification of secondary organic aerosols (SOA) using a Q-ACSM has

21 been comprehensively investigated in this work. SOA samples were generated under simulated

22 photochemical oxidation conditions in a $4.5 \mathrm{~m}^{3}$ Teflon chamber from three different volatile

23 organic compounds (VOC) of atmospheric relevant concentrations (dozens of ppbv): $\alpha$-pinene, 

oxidation states were achieved by changing the relative ratio of the VOC precursor to the oxidants $\left(\mathrm{O}_{3}\right.$ or $\left.\mathrm{OH}\right)$. A scanning mobility particle sizer (SMPS) and an aerosol particle mass analyzer (APM) were used to determine the number-size distribution and the exact mass of the chambergenerated SOA, which were then used to deduce the SOA effective density and mass concentration. Results showed that aerosol mass concentration measured by the Q-ACSM based on SMPS calibration alone may be associated with considerable errors due to the fact that the effective density of SOA at different oxidation state can change substantially. More importantly, the sensitivity of the Q-ACSM to a specific type of SOA was found to be anti-correlated with the aerosol oxidation state regardless of the VOC precursors. This may be due to the decreasing of relative ionization efficiency (RIE) or the collection efficiency (CE) of the Q-ACSM for more oxidized SOA. To pinpoint the actual cause, ammonium sulfate $\left(\left(\mathrm{NH}_{4}\right)_{2} \mathrm{SO}_{4}\right)$ seed particles were injected into the chamber before SOAs were produced and the CE for a specific SOA sample was hence determined with reference to the changes in sulfate signals. Our experiment results along with previous literature reports strongly implied that as the SOA oxidation state increases, SOA will transform gradually from a liquid state $(\mathrm{CE} \approx 1)$ into a solid (or glassy) state with a $\mathrm{CE}$ of $0.2 \sim 0.5$. Meanwhile, the RIE of OA decreased substantially when SOA transformed from hydrocarbon-like OA (HOA) into more oxygenated $\mathrm{OA}(\mathrm{OOA})$ and may further decrease as $\mathrm{O} / \mathrm{C}$ continued to increase. Our results indicated that the current Q-ACSM calibration procedure using a constant RIE may lead to somewhat underestimation of more oxidized OOA but overestimation of less oxidized HOA, i.e., a variable RIE shall be applied, most likely as a function of the SOA oxidation state.

.

Key words: Organic Aerosol; ACSM Calibration; Relative Ionization Efficiency; Collection Efficiency; Effective Density. 


\section{Introduction}

Organic aerosol (OA) have been recognized as a major component in ambient particles, contributing $20-90 \%$ to the total submicron particles around the world (Hallquist et al., 2009a; Kanakidou et al., 2005; Salcedo et al., 2006; Zhang et al., 2007), which can substantially affect the climate directly by interacting with solar radiation and indirectly by affecting cloud microphysics (IPCC, 2014). Recent studies demonstrated that haze events in China were largely driven by secondary organic aerosol (SOA) (Huang et al., 2014) and may exert significant adverse effects on human health (Poschl, 2005; Poschl and Shiraiwa, 2015). The chemical composition and the dramatic changes of $\mathrm{OA}$ in ambient remain less understood compared to the inorganic species. Measurements of OA has been a challenging task not only for the fact that OA contains nearly countless chemical species but also due to its relatively short lifetime and rapid transformation in the atmosphere. Traditionally, the sampling and the ensuing chemical analyses of aerosol composition are mainly utilizing filter based offline methods, followed by analysis with gas chromatography/mass spectrometry (GC/MS), liquid chromatograph/mass spectrometry (LC/MS), nuclear magnetic resonance(NMR) or Fourier transform infrared spectroscopy (FTIR). Evidently, offline techniques cannot catch the dramatic change of ambient OA (Hallquist et al., 2009b). Therefore, many in-situ instrumentations have been developed to conduct aerosol measurements in real time. For example, the particles-into-liquid sampler system (PILS) (Sorooshian et al., 2006) firstly strips out the gas-phase pollutants and dissolves remaining particulate samples into water solutions, which are then send to ion chromatography for further analyses. Clearly, PILS can prevent sample loss by eliminating pre-processing processes. However, only water-soluble components can be analyzed by PILS and no size-resolved measurement can be achieved (Orsini et al., 2003; Weber et al., 2001). Similarly, another widely used thermal-optical organic carbon/elementary carbon (OC/EC) analyzers can only quantify total $\mathrm{OC}$ with very limited information (Birch and Cary, 1996). 

successfully developed and widely deployed to do size-resolved aerosol measurements in real time (Jayne et al., 2000). A typical AMS is equipped with a set of aerodynamic lens (Liu et al., 1995a, b) to effectively focus and transmit particles $(\sim 50-1000 \mathrm{~nm})\left(\mathrm{PM}_{1}\right)$ into the instrument, a time-offlight (ToF) chamber to determine the aerosol size, a thermal vaporizer (heated to $\sim 600^{\circ} \mathrm{C}$ ) to evaporate non-refractory (NR) components into the gas-phase, and a $70 \mathrm{eV}$ electron impact (EI) ionization source to ionize the gaseous samples before they can be analyzed by a mass analyzer (either a quadrupole or a time-of-flight mass spectrometer) (DeCarlo et al., 2004; Jayne et al., 2000). Evidently, compared to previous techniques, AMS can provide elemental composition of the organic species and can achieve much higher time and size resolution. More recently, a newer version of AMS, i.e., the aerosol chemical speciation monitor (ACSM) was developed (Ng et al., 2011). ACSM is basically a simplified AMS without the aerosol ToF chamber and thus is much smaller and affordable. Although ACSM cannot obtain high resolution mass spectra, elementary information can still be readily recovered from some symbolic fragments, such as $\mathrm{C}_{\mathrm{n}} \mathrm{H}_{2 \mathrm{n}+1}(\mathrm{~m} / z 27$, $29,41,43,55,57,69 \ldots)$ and $\mathrm{CO}_{2}^{+}(\mathrm{m} / z 44)$, representing hydrocarbon-like organic aerosol (HOA) and oxygenated organic aerosol (OOA) (Ng et al., 2011). Therefore, ACSM is especially suitable for long term field operation. Nevertheless, Aerodyne AMS/ACSM have been widely used to conduct researches on NR-PM 1 around the world in both field and chamber studies (Zhang et al., 2007; Zhou et al., 2016).

Although the performance of AMS/ACSM has been demonstrated to be in accordance with many other measuring techniques (Drewnick et al., 2003; Jimenez et al., 2016; Kondo et al., 2007; Takegawa et al., 2005), the quantification of aerosol composition by AMS/ACSM still needs to be further refined. In theory, the sensitivity of AMS is affected by the particle transmission efficiency through the aerodynamic lens, the ion transmission efficiency inside the mass analyzer, the particle collection efficiency (CE) by the vaporizer due to the bouncing effect, the ionization efficiency (IE) 
and the possible fragmentation during the thermo-vaporization and EI ionization (70eV) (Allan et

100 al., 2003; Canagaratna et al., 2015; Jayne et al., 2000; Jimenez et al., 2003). In practice, AMS

101 calibrations in terms of CE and IE are mostly conducted with inorganic species only and the

102 calibration factors for organics are indirectly inferred and can be highly uncertain (Jimenez et al., 103 2016).

104 It has been suggested that CE can be affected by particle chemical composition, particle phase, 105 particle size as well as RH. Based on inter-comparisons in sulfate measurements between AMS, 106 PILS-IC and other instruments, a CE of 0.5 for all compounds has been recommended with the 107 assumption that particles are internally mixed (Drewnick et al., 2003; Takegawa et al., 2005). 108 Although organics quantified using a CE of 0.5 has been found correlating well with independent 109 OC or VOCs measurement in most field works (Allan et al., 2004; de Gouw et al., 2005; Takegawa 110 et al., 2005; Venkatachari et al., 2006), studies have shown that CE can vary substantially for 111 various chamber generated organic particles (Bahreini et al., 2005; Docherty et al., 2013).

112 Similarly, IE of inorganic components is usually calibrated directly with ammonium sulfate $113\left(\left(\mathrm{NH}_{4}\right)_{2} \mathrm{SO}_{4}\right)$ and ammonium nitrate $\left(\mathrm{NH}_{4} \mathrm{NO}_{3}\right)$ aerosols of known mass concentration, while the 114 organic components is assigned with a constant relative ionization efficiency (RIE, i.e., the ratio of 115 the electron impact ionization efficiency of a given species to the measured ionization efficiency 116 of nitrate on a per unit mass basis) of 1.4. However, RIE of organic aerosols (RIE org $_{\text {) has been }}$ 117 suggested to be significantly different for different OA species (Murphy, 2016). For instance, it 118 appears that the RIE values of primary OA (POA) are significantly different from those of SOA 119 (Dzepina et al., 2007; Jimenez et al., 2016; Slowik et al., 2004). Any uncertainty associated with 120 the RIE $_{\text {org }}$ may lead to erroneous AMS/ACSM measurement results, especially in the case of 121 interpreting aerosol samples from various environment around the world. Therefore, comprehensive researches on the CE and RIE of different SOA species are of practical importance to constrain the AMS/ACSM measurements. Some methods have been introduced to quantify or 
124 eliminate the side-effects of RIE and CE in AMS measurements. For example, using laser-based

125 vaporizer makes it possible to directly measure aerosol CE (Cross et al., 2007). However, the laser

126 can only be used for particles larger than $250 \mathrm{~nm}$. Most recently, a new type of capture vaporizer

127 has been developed to achieve a unit CE (Hu et al., 2017). However, the capture vaporizer will

128 increase the residence time of aerosol inside the vaporizer and thus change the fragmentation

129 pattern to produce many smaller fragments, which will highly complicate the AMS quantification

130 process

131 In this work, the performance of a quadrupole based ACSM (Q-ACSM) was comprehensively 132 investigated for chamber-generated SOA samples under simulated photochemical oxidation 133 conditions, including both hydroxyl radical $(\mathrm{OH})$ oxidations and ozonolysis $\left(\mathrm{O}_{3}\right)$. Three different 134 volatile organic compounds (VOC) (i.e., $\alpha$-pinene, isoprene, and toluene) at atmospheric relevant 135 concentrations (dozens of ppbv) were chosen to represent both biogenic and anthropogenic VOC.

136 The SOA mass concentrations were directly measured by an aerosol particle mass analyzer (APM)

137 to achieve higher accuracy. The sensitivity of Q-ACSM to SOA at different oxidation state or O/C 138 ratio was quantified.

\section{Experimental Methods}

140

\subsection{Chamber Setup}

A $4.5 \mathrm{~m}^{3}$ collapsible atmospheric-pressure fluoropolymer (Teflon) smog chamber $(\mathrm{L}=1.8 \mathrm{~m}$; $\mathrm{W}=1.5 \mathrm{~m} ; \mathrm{H}=1.7 \mathrm{~m}$ ) (see Fig. 1) was used to generate organic aerosols under atmospheric relevant conditions. The chamber was essentially the same as the one used in our earlier work (Yao et al., 2014; Yuan et al., 2017) and has been described in details previously. Before each set of the experiments, the chamber was thoroughly cleaned by irradiation with black light UV-lamps and exposure to a high concentration (a few ppmv) of $\mathrm{O}_{3}$ for more than 6 hours. Before each experiment, the chamber was flushed by pure air generated by a zero-air generator (Acdco 737) until less than 
14810 particles $\mathrm{cm}^{-3}$ was detected inside the chamber. Reactants and scavengers (if used) were carried

149 into the chamber through a T-shaped glass bulb by pure air. The glass ball was heated gently to

150 insure completely injection. At the bottom center of the smog chamber was installed a Teflon coated

151 fan for rapid mixing of all reactants. The chamber temperature and $\mathrm{RH}$ were maintained at $20 \pm 1^{\circ} \mathrm{C}$

152 and $10 \%-15 \%$, respectively.

\subsection{SOA Generation}

154 During each experiment, known amount of $\alpha$-pinene (Sigma-Aldrich, $>98 \%$ ), isoprene 155 (Sigma-Aldrich, $>99 \%$ ), or toluene (Sigma-Aldrich, $>99.5 \%$ ) was firstly dissolved into 156 cyclohexane (TEDIA Inc., HPLC grade $>99.5 \%$ ) and then was injected into the chamber through

157 a stream of pure air. The concentrations of these precursor VOCs were set to atmospheric relevant 158 levels to make the results of this work more applicable to ambient measurements. Ozone was 159 generated by exposing pure oxygen $\left(\mathrm{O}_{2}\right)$ to a low-pressure mercury $(\mathrm{Hg})$ lamp (Jelight, Model 600).

160 When $\mathrm{O}_{3}$ was used as the oxidant, $\mathrm{OH}$ radical scavenger, cyclohexane, was injected into the

161 chamber before the experiment. When $\mathrm{OH}$ was used as the oxidant, trace amount of self-

162 synthesized methyl nitrite was firstly injected into the chamber and then the black light bulbs

163 around the chamber were turned on for several minutes to start the $\mathrm{OH}$-initiated oxidations (Yao et

164 al., 2014). The mixing ratios of $\mathrm{O}_{3}$ inside the chamber was monitored continuously by a Thermo

165 Fisher Scientific ozone monitor (Model 49i) throughout the experiment. Different SOA oxidation states were achieved by changing the ratio between the VOC precursor and the oxidant $\left(\mathrm{O}_{3}\right.$ or $\left.\mathrm{OH}\right)$.

\section{$2.3 Q$-ACSM Operation}


173 the procedure described by $\mathrm{Ng}$ et al. (2011). The measured organic mass concentration was

174 calculated using a default RIE value of 1.4 and a CE value of 0.5 , which have been widely used

175 during most of the field and laboratory measurements (Canagaratna et al., 2007). The nitrogen $\left(\mathrm{N}_{2}\right)$

176 peak $(m / z=28)$ and the internal naphthalene standard peak $(m / z=128)$ were used before the experiment to do mass calibration. The mass dependent transmission efficiency of the Q-mass spectrometer was also calibrated before data analyses.

\subsection{Aerosol Mass Measurement}

A scanning mobility particle sizer (SMPS), consisting of a differential mobility analyzer

181 (DMA, TSI Model 3081) and a condensation particle counter (CPC, TSI Model 3776), was used

182 for real-time monitoring of the particle number size distribution between $15 \mathrm{~nm}-650 \mathrm{~nm}$ particles

183 and aerosol volume concentrations were deduced assuming spherical shape. The time resolution

184 was 5 mins. An aerosol particle mass analyzer (APM, Kanomax Model 3601) combined with a

185 DMA (TSI Model 3081) and a CPC (TSI Model 3776) were used to determine the particle mass

186 and thus the particle effective density $(\rho)$ was calculated from the measured mobility diameter

187 (DeCarlo et al., 2004; McMurry et al., 2002). During each experiment, the diameter of the particle

188 to be analyzed by the APM was manually set to be the same as the peak value of the particle number

189 size distribution measured by the SMPS, as the particles were continuously growing in the chamber.

190 One DMA-APM scan took about 5 mins. Hence, the particle mass concentration was calculated

191 from the measured particle volume concentration and the corresponding effective density.

\section{3. Results and Discussion}

\subsection{Determine the Q-ACSM Response Factor for Chamber Generated SOA}


196 nucleation event occurred and was marked by a typical banana-shaped three-dimensional (3-D)

197 number size distribution plot (Fig. 2a). Figure 2b showed the time series of aerosol mass

198 concentrations measured by Q-ACSM, integrated from SMPS measurements, and the

199 corresponding $\mathrm{f} 44$ (the ratio of $\mathrm{m} / \mathrm{z} 44$ signal over total organic ion signal intensity) and effective

200 density of aerosol calculated from the Q-ACSM and APM measurements, respectively. Since $m / z$

20144 signal basically reflected the oxygen content in $\mathrm{OA}$, the $\mathrm{O} / \mathrm{C}$ ratio can be deduced directly from

202 f44, both of which have been widely used to represent the oxidation state of OA (Canagaratna et

203 al., 2015). The number size-distributions at one hour interval during the chamber experiment were

204 also depicted in Fig. 2c. Evidently, as the ozonolysis reaction proceeded, the size and mass

205 concentration of the aerosol swiftly increased, especially during the initial two hours. The effective

206 density of the formed aerosol also increased as the aerosol became more compact and approached a spherical shape. The initial high values of $\mathrm{f} 44$ may be due to the fact that initially formed SOA particles were highly oxidized because of gas/particle partitioning (Shilling et al., 2009a). The f44 factor in the following period fluctuated between 0.115 and 0.135 , indicating that the oxidation state of aerosols did not change significantly within the experimental period. After $2 \sim 3$ hours, the aerosol size reached $80 \sim 100 \mathrm{~nm}$, mass concentration increased to $40 \sim 50 \mu \mathrm{g} \mathrm{m}^{-3}$, and the effective density and $\mathrm{f} 44$ were about $1.2 \mathrm{~g} \mathrm{~cm}^{-3}$ and 0.13 , respectively. By then a relative steady-state was reached and the response factor (RF) of the Q-ACSM was thus determined through a linear correlation analysis using the relative steady-state data, as shown in Fig. 3.

In a similarly way, fourteen independent chamber experiments were conducted in this work. all reached relatively steady states. The slight variation of $\mathrm{f} 44$ after reaching relatively steady state in each experiment was mainly due to the measurement uncertainty associated with the Q-ACSM.

219 The VOC used in this work included $\alpha$-pinene, isoprene, and toluene, representing both biogenic and anthropogenic VOC emissions. Both ozonolysis and $\mathrm{OH}$ initiated oxidation processes were 

samples under atmospheric relevant conditions and thus avoid secondary VOC oxidation products, the mixing ratios of these VOC precursors ranged from 10 to $60 \mathrm{ppbv}$ for $\alpha$-pinene, 60 to $200 \mathrm{ppbv}$ for isoprene, and 30 to $60 \mathrm{ppbv}$ for toluene. The oxidant concentrations were also limited to 50-80 ppbv for $\mathrm{O}_{3}$ and $50-300 \mu \mathrm{L}$ for methyl nitrite. The detailed experimental conditions and results were listed in Table 1.

\subsection{Effects of f44}

To investigate the effects of oxidation state of the SOA samples (i.e., the measured f44) on the Q-ACSM detection sensitivity, for each pair of VOC/oxidant several experiments were repeated with different relative concentration ratio between the VOC and the oxidant. Evidently, the characteristics of the generated SOA from the oxidation of isoprene, $\alpha$-pinene, and toluene appeared to be significantly different among various oxidation conditions. Especially the RF of the Q-ACSM changed substantially for different $\mathrm{f} 44$. Both isoprene and $\alpha$-pinene are relatively reactive toward $\mathrm{O}_{3}$ and $\mathrm{OH}$. However, the dominant degradation processes in the atmosphere for isoprene and $\alpha$-pinene are typically through oxidations by $\mathrm{OH}$ and $\mathrm{O}_{3}$, respectively. Especially, laboratory studies have shown that the ozonolysis of $\alpha$-pinene can lead to considerably higher SOA yield than that from $\mathrm{OH}$ initiated reactions (Yao et al., 2014). Therefore, in this work we were focusing on the isoprene- $\mathrm{OH}$ and $\alpha$-pinene- $\mathrm{O}_{3}$ reactions only. In the case of toluene, the experiment was relatively straightforward since toluene only reacted with $\mathrm{OH}$ radicals. The oxidation states of SOA generated in each experiment was shown in different colors in triangle plot (see Fig. 4). Since some $\mathrm{O}_{3}$ will be produced during $\mathrm{OH}$ initiated chain reactions (Finlayson-Pitts and Pitts, 1999), the oxidation state of isoprene-generated SOA varied more significantly as the experiment proceed.

243 For $\alpha$-pinene, however, f44 did not vary considerably as isoprene during the one experiment period 244 and in between experiments. Even when $\mathrm{O}_{3}$ to $\alpha$-pinene ratio was increased substantially, only 245 slight increase in $\mathrm{f} 44$ was observed, which was most likely due to the fact that the first-generation 
oxidation products of $\alpha$-pinene were mainly partitioned into the aerosol phase and cannot be further oxidized by $\mathrm{O}_{3}$. Nevertheless, the Q-ACSM RF for all chamber-generated SOA decreased linearly as the $\mathrm{f} 44$ increased (see Fig. 5a).

The effective density of all chamber-generated SOA ranged between $1.09-1.36 \mathrm{~g} \mathrm{~cm}^{-3}$, which covered a much larger range compared to the reported values of 1.22-1.28 by Zelenyuk et al. (2008) and $1.3 \pm 0.1$ by Kiendler-Scharr et al. (2009) for biogenic SOA. Also, clearly shown in Fig. 5b was

252 that the SOA effective density increased linearly with increasing f44, most likely due to the fact

253 that when more oxidants were present, more highly oxygenated products were produced and led to

254 the formation of more compact SOA. Our results indicated that the oxidation state and effective density of atmospheric SOA may vary significantly from different ambient oxidation environment and can change dynamically at different stage of the aging process. Therefore, it was reasonable to assume that quantification of ambient OA by Q-ACSM using a constant conversion factor may induce significant error in aerosol mass concentration. Accordingly, the Q-ACSM RF for OA should be systematically calibrated with laboratory-generated aerosols produced not only from various VOC precursors but also under different atmospheric-relevant reaction conditions. reference and can be mathematically expressed as the product of three factors:

i.e., the ionization efficiency of nitrate salt $\left(\mathrm{IE}_{\mathrm{NO} 3}\right)$, the relative ionization efficiency of $\mathrm{OA}\left(\mathrm{RIE}_{\mathrm{org}}\right)$, and the collection efficiency of $\mathrm{OA}\left(\mathrm{CE}_{\mathrm{org}}\right)$ of the Q-ACSM. $\mathrm{IE}_{\mathrm{NO} 3}$ can be calibrated before and after the experiments and is independent from the properties of OA. However, the other two terms may vary with different OA samples, the observed anti-correlation of RF with $\mathrm{f} 44$ could be due to either CE or RIE. 
To investigate and evaluate the possibility that CE may contribute to the observed anticorrelations between RF and $\mathrm{f} 44$ in this work, a set of chamber experiments using $\left(\mathrm{NH}_{4}\right)_{2} \mathrm{SO}_{4}(\mathrm{AS})$ seed particles were conducted. The difference between this set of experiments from the previous ones was that here nebulized dry AS seed particles were injected into the chamber before the SOA was produced, i.e., the gas phase products will condense onto the AS seed surface instead of initiating new particle formation. After fully coated with SOA, the measured sulfate mass concentration by Q-ACSM will change due to variation in $\mathrm{CE}_{\mathrm{SO} 4}$ and the $\mathrm{CE}$ of $\mathrm{SOA}$ material $\left(\mathrm{CE}_{\text {org }}\right)$ can be deduced accordingly. In each experiment, similar amount and size of AS seeds were used to avoid other possible affecting factors. Figure 6 displayed the time series of a typical AS chamber experiment. Initially, AS seed aerosol was injected and ACSM measured sulfate mass concentration was about $35 \mu \mathrm{g} \mathrm{m}^{-3}$. After VOC precursor was injected, the ACSM measured sulfate 281 increased rapidly to about $50 \mu \mathrm{g} \mathrm{m}^{-3}$. As shown in Fig. 6, the sulfate signal increased substantially after coated with SOA but the measured 444 did not change significantly as SOA was continuously produced. Thus, $\mathrm{CE}_{\text {org }}$ at certain $\mathrm{f} 44$ can be evaluated. Evidently, the accuracy of the absolute value of $\mathrm{CE}_{\text {org }}$ will depend on $\mathrm{CE}_{\mathrm{SO} 4}$ and $\mathrm{RIE}_{\mathrm{SO} 4}$. It is worth noting that $\mathrm{CE}_{\mathrm{SO} 4}$ may vary from 0.2 to 1 as a function of RH (Matthew et al., 2008). $\mathrm{CE}_{\mathrm{SO} 4}$ was measured to be 0.28 in this work with $\mathrm{RH}<15 \%$. In the case of $\mathrm{RIE}_{\mathrm{SO} 4}$, a value of 1.15 was used here as suggested by other studies (Canagaratna et al., 2007; Ng et al., 2011; Petit et al., 2015). Although recent researches have shown that RIE $\mathrm{SO}_{4}$ may vary from instrument to instrument (Budisulistiorini et al., 2014; Crenn et al., 2015), the exact $\mathrm{RIE}_{\mathrm{SO} 4}$ value would not affect the conclusion of this research. For the scope of this work, only the relative changes in sulfate concentration were noted. conditions and results were listed in Table 2. However, $\mathrm{CE}_{\text {org }}$ appeared to be affected by the SOA coating thickness (see Fig. 7), which would decide the mixing state of the SOA coated AS particles. 
was a possibility that the seed core would hit the collection surface directly and thus behaved as an AS particle. To demonstrate this possibility, an experiment under extreme condition was conducted, i.e., substantially excess VOC precursor was added. The result was indicated by the red point in Fig. 7. This near unit CE ( 0.97) suggested that the AS aerosols were fully covered with SOA and behaved as a pure SOA, which may assume a "sticky" liquid state. However, no higher f44 values could be achieved with such large amount of organics generated, which was possibly related to the loading-dependent gas-particle partitioning (Shilling et al., 2009b) and made it difficult to address f44 influence on $\mathrm{CE}_{\text {org }}$ via experiment. The coating layer of the light blue points should be thick enough to cover the AS core, which was indicated by the decreasing $\mathrm{CE}_{\text {org }}$ from 1 to $\sim 0.5$ with increasing f44. However, there was still a possibility that the CE values of these light blue points were the results of a combination of AS core and organic shell. (Kiendler-Scharr et al., 2009) and field measurements conducted in amazon, where aerosols were dominated by liquid SOA (Allan et al., 2014; Chen et al., 2009). However recently, it has been proposed in theoretical, chamber, and field studies that organic particles can exist in semi-solid or solid state under ambient temperature, rather than been in liquid state (Shiraiwa et al., 2011; Vaden et al., 2010; Virtanen et al., 2010).

The oxidation products of VOCs under ambient conditions are mainly consisted of carbonyl compounds and carboxylic acids (Finlayson-Pitts and Pitts, 1999), the saturation vapor pressures of which normally decrease with increasing oxidation level. As they are more oxidized, SOA may transit from liquid phase gradually into solid phase under ambient temperature, which are consistent with our observations of higher effective density at higher oxidation state. Accordingly, the surface property of SOA can change dramatically and may induce considerable change in CE as SOA

318 transforms from a "sticky" liquid-drop into a "bouncing" solid-ball. Particle morphology research based on glass transition temperature $\left(\mathrm{T}_{\mathrm{g}}\right)$ indicated that during oxidation, the SOA particles will 

and under different RH, with a value ranging from 0.2 to $~ 1$ (Alfarra, 2004; Docherty et al., 2013).

\subsection{Effects of RIE} et al., 2003):

$$
\text { RIEs }=\frac{\mathrm{MW}_{\mathrm{N} 03}}{\mathrm{IE}_{\mathrm{N} 03}} \cdot \frac{\mathrm{IEs}}{\mathrm{MWs}},
$$

where RIEs is the relative ionization efficiency for a specific organic molecule S. IEs and MWs are respectively the ionization efficiency and the molecular weight of S. Theoretically, IEs is directly proportion to $\sigma$, i.e., the electron impact ionization cross section of the molecule, which is linearly related to the number of electrons in the molecule. Since the number of electrons is roughly proportional to the molecular weight, RIEs of molecules with similar structure and function groups are suggested to be similar to each other. RIEs values for hydrocarbons and oxygenated species, however, are believed to be different since their oxygen contents can vary substantially

335 (Canagaratna et al., 2007), ranging from less than 1 to more than 3 (Dzepina et al., 2007; Jimenez

336 et al., 2016; Slowik et al., 2004). Consequently, the anti-correlation between RF and f44 may also

337 due to different RIEs related to the oxygen contents.

\section{Conclusion}

The sensitivity of Q-ACSM to chamber-generated SOA in various oxidation states was 340 comprehensively investigated and an anti-correlation between the instrument sensitivity, RF, and

341 SOA oxidation state, represented by f44, was obtained regardless of the type of VOC precursors.

342 Therefore, our results strongly indicated that ambient OA measurements by Q-ACSM using a 
constant conversion factor may induce significant error in aerosol mass concentration. Accordingly,

344 the Q-ACSM RF for OA should be systematically calibrated with laboratory-generated aerosols

345 produced not only from various VOC precursors but also under different atmospheric-relevant

346 reaction conditions. Based on our chamber experiment results and previously reported observation

347 in chamber and ambient studies, a comprehensive view of $\mathrm{RF}_{\text {org }}, \mathrm{RIE}_{\text {org }}, \mathrm{CE}_{\text {org }}$, and $\rho_{\text {effective }}$ of OA

348 at different oxidation state (indicated by f44) was proposed (see Fig. 8). It was reasonably to assume

349 that as a SOA particle was in low oxidation state, it was basically in liquid state with a CE of close

350 to one. With the increase of $\mathrm{O} / \mathrm{C}$, the liquid state slowly changed into semi-solid and finally the

351 solid/glassy state with a CE ranging from 0.2 0.5. The RIE of organics would decrease

352 substantially from hydrocarbon-like compounds to oxygen containing compounds but would only

353 continue to decrease at a slower rate with further increasing $\mathrm{O} / \mathrm{C}$. The observed anti-correlation

354 between $\mathrm{RF}$ and $\mathrm{O} / \mathrm{C}$ in this work can be explained by the combined effects of CE and RIE. Our

355 results suggested that under certain circumstance a Q-ACSM calibrated using the traditional

356 method may underestimate OOA content but overestimate HOA in previous studies. Accordingly,

357 different RIE $_{\text {org }}$ values should be used for HOA and OOA. In addition, early AMS calibrations

358 based on SMPS measured mass concentration may be associated with considerable errors due to

359 the fact that the effective density of SOA at different oxidation state can change substantially.

\section{Acknowledgements}

This work is supported by the National Key Research and Development Project (2016YFC0202401), National Natural Science Foundation of China (41575122, 41675126, and 41730106), and the Priority Academic Program Development of Jiangsu Higher Education Institutions. The data used are listed in the tables and references. The data used in this work are available from the authors upon request (zheng.jun@,nuist.edu.cn). 


\section{References}

Alfarra, M.: Insights into atmospheric organic aerosols using an aerosol mass spectrometer, University of Manchester, 2004.

Allan, J. D., Alfarra, M. R., Bower, K. N., Williams, P. I., Gallagher, M. W., Jimenez, J. L., McDonald, A. G., Nemitz, E., Canagaratna, M. R., Jayne, J. T., Coe, H., and Worsnop, D. R.: Quantitative sampling using an Aerodyne aerosol mass spectrometer: 2. Measurements of fine particulate chemical composition in two UK cities, J. Geophys. Res.-Atmos., 108, 10.1029/2003jd001608, 2003.

Allan, J. D., Bower, K. N., Coe, H., Boudries, H., Jayne, J. T., Canagaratna, M. R., Millet, D. B., Goldstein, A. H., Quinn, P. K., Weber, R. J., and Worsnop, D. R.: Submicron aerosol composition at Trinidad Head, California, during ITCT 2K2: Its relationship with gas phase volatile organic carbon and assessment of instrument performance, J. Geophys. Res.-Atmos., 109, 10.1029/2003jd004208, 2004.

Allan, J. D., Morgan, W. T., Darbyshire, E., Flynn, M. J., Williams, P. I., Oram, D. E., Artaxo, P., Brito, J., Lee, J. D., and Coe, H.: Airborne observations of IEPOX-derived isoprene SOA in the Amazon during SAMBBA, Atmos Chem Phys, 14, 11393-11407, 10.5194/acp-14-11393-2014, 2014.

Bahreini, R., Keywood, M. D., Ng, N. L., Varutbangkul, V., Gao, S., Flagan, R. C., Seinfeld, J. H., Worsnop, D. R., and Jimenez, J. L.: Measurements of secondary organic aerosol from oxidation of cycloalkenes, terpenes, and m-xylene using an Aerodyne aerosol mass spectrometer, Environ. Sci. Technol., 39, 5674-5688, 10.1021/es048061a, 2005.

Birch, M. E., and Cary, R. A.: Elemental carbon-based method for monitoring occupational exposures to particulate diesel exhaust, Aerosol Sci. Technol., 25, 221-241, 10.1080/02786829608965393, 1996.

Budisulistiorini, S. H., Canagaratna, M. R., Croteau, P. L., Baumann, K., Edgerton, E. S., Kollman, M. S., Ng, N. L., Verma, V., Shaw, S. L., Knipping, E. M., Worsnop, D. R., Jayne, J. T., Weber, R. J., and Surratt, J. D.: Intercomparison of an Aerosol Chemical Speciation Monitor (ACSM) with ambient fine aerosol measurements in downtown Atlanta, Georgia, Atmos. Meas. Tech., 7, 19291941, 10.5194/amt-7-1929-2014, 2014.

Canagaratna, M. R., Jayne, J. T., Jimenez, J. L., Allan, J. D., Alfarra, M. R., Zhang, Q., Onasch, T. B., Drewnick, F., Coe, H., Middlebrook, A., Delia, A., Williams, L. R., Trimborn, A. M., Northway, M. J., DeCarlo, P. F., Kolb, C. E., Davidovits, P., and Worsnop, D. R.: Chemical and microphysical characterization of ambient aerosols with the aerodyne aerosol mass spectrometer, Mass Spectrom. Rev., 26, 185-222, 10.1002/mas.20115, 2007. 
402

403

404

405

406

407

408

409

410

411

412

413

414

415

416

417

418

419

420

421

Canagaratna, M. R., Jimenez, J. L., Kroll, J. H., Chen, Q., Kessler, S. H., Massoli, P., Hildebrandt Ruiz, L., Fortner, E., Williams, L. R., Wilson, K. R., Surratt, J. D., Donahue, N. M., Jayne, J. T., and Worsnop, D. R.: Elemental ratio measurements of organic compounds using aerosol mass spectrometry: characterization, improved calibration, and implications, Atmos. Chem. Phys., 15, 253-272, 10.5194/acp-15-253-2015, 2015.

Chen, Q., Farmer, D. K., Schneider, J., Zorn, S. R., Heald, C. L., Karl, T. G., Guenther, A., Allan, J. D., Robinson, N., Coe, H., Kimmel, J. R., Pauliquevis, T., Borrmann, S., Poeschl, U., Andreae, M. O., Artaxo, P., Jimenez, J. L., and Martin, S. T.: Mass spectral characterization of submicron biogenic organic particles in the Amazon Basin, Geophys. Res. Letts., 36, 10.1029/2009g1039880, 2009.

Crenn, V., Sciare, J., Croteau, P. L., Verlhac, S., Froehlich, R., Belis, C. A., Aas, W., Aijala, M., Alastuey, A., Artinano, B., Baisnee, D., Bonnaire, N., Bressi, M., Canagaratna, M., Canonaco, F., Carbone, C., Cavalli, F., Coz, E., Cubison, M. J., Esser-Gietl, J. K., Green, D. C., Gros, V., Heikkinen, L., Herrmann, H., Lunder, C., Minguillon, M. C., Mocnik, G., O'Dowd, C. D., Ovadnevaite, J., Petit, J. E., Petralia, E., Poulain, L., Priestman, M., Riffault, V., Ripoll, A., SardaEsteve, R., Slowik, J. G., Setyan, A., Wiedensohler, A., Baltensperger, U., Prevot, A. S. H., Jayne, J. T., and Favez, O.: ACTRIS ACSM intercomparison - Part 1: Reproducibility of concentration and fragment results from 13 individual Quadrupole Aerosol Chemical Speciation Monitors (QACSM) and consistency with co-located instruments, Atmos. Meas. Tech., 8, 5063-5087, 10.5194/amt-8-5063-2015, 2015.

Cross, E. S., Slowik, J. G., Davidovits, P., Allan, J. D., Worsnop, D. R., Jayne, J. T., Lewis, D. K., Canagaratna, M., and Onasch, T. B.: Laboratory and ambient particle density determinations using light scattering in conjunction with aerosol mass spectrometry, Aerosol Sci. Technol., 41, 343-359, 10.1080/02786820701199736, 2007.

de Gouw, J. A., Middlebrook, A. M., Warneke, C., Goldan, P. D., Kuster, W. C., Roberts, J. M., Fehsenfeld, F. C., Worsnop, D. R., Canagaratna, M. R., Pszenny, A. A. P., Keene, W. C., Marchewka, M., Bertman, S. B., and Bates, T. S.: Budget of organic carbon in a polluted atmosphere: Results from the New England Air Quality Study in 2002, J. Geophys. Res.-Atmos., 110, 10.1029/2004jd005623, 2005.

DeCarlo, P. F., Slowik, J. G., Worsnop, D. R., Davidovits, P., and Jimenez, J. L.: Particle morphology and density characterization by combined mobility and aerodynamic diameter measurements. Part 1: Theory, Aerosol Sci. Technol., 38, 1185-1205, 10.1080/027868290903907, 2004.

Docherty, K. S., Jaoui, M., Corse, E., Jimenez, J. L., Offenberg, J. H., Lewandowski, M., and Kleindienst, T. E.: Collection Efficiency of the Aerosol Mass Spectrometer for Chamber-Generated Secondary Organic Aerosols, Aerosol Sci. Technol., 47, 294-309, 10.1080/02786826.2012.752572, 2013. 
442 Dzepina, K., Arey, J., Marr, L. C., Worsnop, D. R., Salcedo, D., Zhang, Q., Onasch, T. B., Molina, 443 L. T., Molina, M. J., and Jimenez, J. L.: Detection of particle-phase polycyclic aromatic 444 hydrocarbons in Mexico City using an aerosol mass spectrometer, Int. J. Mass spectrom., 263, 152$445170,10.1016 /$ j.ijms.2007.01.010, 2007. experiments and applications, Academic Press, San Diego, Calif., xxii, 969 pp., 1999.

Hallquist, M., Wenger, J. C., Baltensperger, U., Rudich, Y., Simpson, D., Claeys, M., Dommen, J., Donahue, N. M., George, C., Goldstein, A. H., Hamilton, J. F., Herrmann, H., Hoffmann, T., Iinuma, Y., Jang, M., Jenkin, M. E., Jimenez, J. L., Kiendler-Scharr, A., Maenhaut, W., McFiggans, G., Mentel, T. F., Monod, A., Prevot, A. S. H., Seinfeld, J. H., Surratt, J. D., Szmigielski, R., and issues, Atmos. Chem. Phys., 9, 5155-5236, 2009a.

Hallquist, M., Wenger, J. C., Baltensperger, U., Rudich, Y., Simpson, D., Claeys, M., Dommen, J., Donahue, N. M., George, C., Goldstein, A. H., Hamilton, J. F., Herrmann, H., Hoffmann, T., Iinuma, Y., Jang, M., Jenkin, M. E., Jimenez, J. L., Kiendler-Scharr, A., Maenhaut, W., McFiggans, G., Mentel, T. F., Monod, A., Prevot, A. S. H., Seinfeld, J. H., Surratt, J. D., Szmigielski, R., and Wildt, J.: The formation, properties and impact of secondary organic aerosol: current and emerging issues, Atmos. Chem. Phys., 9, 5155-5236, 2009 b.

Hu, W., Campuzano-Jost, P., Day, D. A., Croteau, P., Canagaratna, M. R., Jayne, J. T., Worsnop, D. R., and Jimenez, J. L.: Evaluation of the new capture vaporizer for aerosol mass spectrometers (AMS) through field studies of inorganic species, Aerosol Sci. Technol., 51, 735-754, 10.1080/02786826.2017.1296104, 2017. Ciarelli, G., Piazzalunga, A., Schwikowski, M., Abbaszade, G., Schnelle-Kreis, J., Zimmermann, R., An, Z., Szidat, S., Baltensperger, U., Haddad, I. E., and Prevot, A. S. H.: High secondary aerosol contribution to particulate pollution during haze events in China, Nature, 514, 218-222, 10.1038 /nature 13774 

submicron particles, Aerosol Sci. Technol., 33, 49-70, 10.1080/027868200410840, 2000.

Jimenez, J. L., Jayne, J. T., Shi, Q., Kolb, C. E., Worsnop, D. R., Yourshaw, I., Seinfeld, J. H., Flagan, R. C., Zhang, X. F., Smith, K. A., Morris, J. W., and Davidovits, P.: Ambient aerosol sampling using the Aerodyne Aerosol Mass Spectrometer, J. Geophys. Res.-Atmos., 108, 10.1029/2001jd001213, 2003.

Jimenez, J. L., Canagaratna, M. R., Drewnick, F., Allan, J. D., Alfarra, M. R., Middlebrook, A. M., Slowik, J. G., Zhang, Q., Coe, H., Jayne, J. T., and Worsnop, D. R.: Comment on "The effects of molecular weight and thermal decomposition on the sensitivity of a thermal desorption aerosol mass spectrometer", Aerosol Sci. Technol., 50, I-XV, 10.1080/02786826.2016.1205728, 2016.

Kanakidou, M., Seinfeld, J. H., Pandis, S. N., Barnes, I., Dentener, F. J., Facchini, M. C., Van Dingenen, R., Ervens, B., Nenes, A., Nielsen, C. J., Swietlicki, E., Putaud, J. P., Balkanski, Y., Fuzzi, S., Horth, J., Moortgat, G. K., Winterhalter, R., Myhre, C. E. L., Tsigaridis, K., Vignati, E., Stephanou, E. G., and Wilson, J.: Organic aerosol and global climate modelling: a review, Atmos. Chem. Phys., 5, 1053-1123, 2005.

Kiendler-Scharr, A., Zhang, Q., Hohaus, T., Kleist, E., Mensah, A., Mentel, T. F., Spindler, C., Uerlings, R., Tillmann, R., and Wildt, J.: Aerosol Mass Spectrometric Features of Biogenic SOA: Observations from a Plant Chamber and in Rural Atmospheric Environments, Environ. Sci. Technol., 43, 8166-8172, 10.1021/es901420b, 2009.

Kondo, Y., Miyazaki, Y., Takegawa, N., Miyakawa, T., Weber, R. J., Jimenez, J. L., Zhang, Q., and Worsnop, D. R.: Oxygenated and water-soluble organic aerosols in Tokyo, J. Geophys. Res.Atmos., 112, 10.1029/2006jd007056, 2007.

Koop, T., Bookhold, J., Shiraiwa, M., and Pöschl, U.: Glass transition and phase state of organic compounds: dependency on molecular properties and implications for secondary organic aerosols in the atmosphere, Physical Chemistry Chemical Physics, 13, 19238-19255, 2011.

Liu, P., Ziemann, P. J., Kittelson, D. B., and McMurry, P. H.: Generating particle beams of controlled dimensions and divergence .1. Theory of particle motion in aerodynamic lenses and nozzle expansions, Aerosol Sci. Technol., 22, 293-313, 10.1080/02786829408959748, 1995a.

Liu, P., Ziemann, P. J., Kittelson, D. B., and McMurry, P. H.: Generating particle beams of controlled dimensions and divergence .2. Experimental evaluation of particle motion in aerodynamic lenses and nozzle expansions, Aerosol Sci. Technol., 22, 314-324, 10.1080/02786829408959749, 1995 b. 
Matthew, B. M., Middlebrook, A. M., and Onasch, T. B.: Collection efficiencies in an Aerodyne Aerosol Mass Spectrometer as a function of particle phase for laboratory generated aerosols, Aerosol Sci. Technol., 42, 884-898, 10.1080/02786820802356797, 2008.

McMurry, P. H., Wang, X., Park, K., and Ehara, K.: The relationship between mass and mobility for atmospheric particles: A new technique for measuring particle density, Aerosol Sci. Technol., 36, 227-238, 10.1080/027868202753504083, 2002.

Murphy, D. M.: The effects of molecular weight and thermal decomposition on the sensitivity of a thermal desorption aerosol mass spectrometer, Aerosol Sci. Technol., 50, 118-125, 10.1080/02786826.2015.1136403, 2016.

Ng, N. L., Herndon, S. C., Trimborn, A., Canagaratna, M. R., Croteau, P. L., Onasch, T. B., Sueper, D., Worsnop, D. R., Zhang, Q., Sun, Y. L., and Jayne, J. T.: An Aerosol Chemical Speciation Monitor (ACSM) for Routine Monitoring of the Composition and Mass Concentrations of Ambient Aerosol, Aerosol Sci. Technol., 45, 780-794, 10.1080/02786826.2011.560211, 2011.

Orsini, D. A., Ma, Y. L., Sullivan, A., Sierau, B., Baumann, K., and Weber, R. J.: Refinements to the particle-into-liquid sampler (PILS) for ground and airborne measurements of water soluble aerosol composition, Atmos. Environ., 37, 1243-1259, 10.1016/s1352-2310(02)01015-4, 2003.

Petit, J. E., Favez, O., Sciare, J., Crenn, V., Sarda-Esteve, R., Bonnaire, N., Mocnik, G., Dupont, J. C., Haeffelin, M., and Leoz-Garziandia, E.: Two years of near real-time chemical composition of submicron aerosols in the region of Paris using an Aerosol Chemical Speciation Monitor (ACSM) and a multi-wavelength Aethalometer, Atmos. Chem. Phys., 15, 2985-3005, 10.5194/acp-15-2985$2015,2015$.

Poschl, U.: Atmospheric aerosols: Composition, transformation, climate and health effects, Angewandte Chemie-International Edition, 44, 7520-7540, 10.1002/anie.200501122, 2005.

Poschl, U., and Shiraiwa, M.: Multiphase Chemistry at the Atmosphere-Biosphere Interface Influencing Climate and Public Health in the Anthropocene, Chemical Reviews, 115, 4440-4475, $10.1021 / \mathrm{cr} 500487 \mathrm{~s}, 2015$.

Salcedo, D., Onasch, T. B., Dzepina, K., Canagaratna, M. R., Zhang, Q., Huffman, J. A., DeCarlo, P. F., Jayne, J. T., Mortimer, P., Worsnop, D. R., Kolb, C. E., Johnson, K. S., Zuberi, B., Marr, L. C., Volkamer, R., Molina, L. T., Molina, M. J., Cardenas, B., Bernabe, R. M., Marquez, C., Gaffney, J. S., Marley, N. A., Laskin, A., Shutthanandan, V., Xie, Y., Brune, W., Lesher, R., Shirley, T., and Jimenez, J. L.: Characterization of ambient aerosols in Mexico City during the MCMA-2003 campaign with Aerosol Mass Spectrometry: results from the CENICA Supersite, Atmos. Chem. Phys., 6, 925-946, 2006. 

composition of $\alpha$-pinene SOA particles, Atmos. Chem. Phys., 9, 771-782, 10.5194/acp-9-7712009, 2009a. composition of alpha-pinene SOA particles, Atmos. Chem. Phys., 9, 771-782, $2009 \mathrm{~b}$. organic aerosol particles, Proc. Natl. Acad. Sci. USA, 108, 11003-11008, 2011.

Slowik, J. G., Stainken, K., Davidovits, P., Williams, L. R., Jayne, J. T., Kolb, C. E., Worsnop, D. R., Rudich, Y., DeCarlo, P. F., and Jimenez, J. L.: Particle morphology and density characterization by combined mobility and aerodynamic diameter measurements. Part 2: Application to combustion-generated soot aerosols as a function of fuel equivalence ratio, Aerosol Sci. Technol., $55438,1206-1222,10.1080 / 027868290903916,2004$. 40, 396-409, 10.1080/02786820600632282, 2006.

Takegawa, N., Miyazaki, Y., Kondo, Y., Komazaki, Y., Miyakawa, T., Jimenez, J. L., Jayne, J. T., Spectrometer (AMS): Intercomparison with other aerosol instruments, Aerosol Sci. Technol., 39, 760-770, 10.1080/02786820500243404, 2005. and secondary organic particles and the adsorption of spectator organic gases during aerosol formation, Proc. Natl. Acad. Sci. USA, 107, 6658-6663, 2010. O., Felton, D., and Rattigan, O.: An intercomparison of measurement methods for carbonaceous aerosol in the ambient air in New York City, Aerosol Sci. Technol., 40, 788-795, 10.1080/02786820500380289, 2006. 
578 Yuan, C., Ma, Y., Diao, Y. W., Yao, L., Zhou, Y. Y., Wang, X., and Zheng, J.: CCN activity of Takami, A., Middlebrook, A. M., Sun, Y. L., Dzepina, K., Dunlea, E., Docherty, K., DeCarlo, P. F., Salcedo, D., Onasch, T., Jayne, J. T., Miyoshi, T., Shimono, A., Hatakeyama, S., Takegawa, N., Kondo, Y., Schneider, J., Drewnick, F., Borrmann, S., Weimer, S., Demerjian, K., Williams, P., Bower, K., Bahreini, R., Cottrell, L., Griffin, R. J., Rautiainen, J., Sun, J. Y., Zhang, Y. M., and Worsnop, D. R.: Ubiquity and dominance of oxygenated species in organic aerosols in anthropogenically-influenced Northern Hemisphere midlatitudes, Geophys. Res. Letts., 34,

592 Zhou, W., Jiang, J., Duan, L., and Hao, J.: Evolution of Submicrometer Organic Aerosols during a 593 Complete Residential Coal Combustion Process, Environ. Sci. Technol., 50, 7861-7869, 594 10.1021/acs.est.6b00075, 2016. 
Atmos. Meas. Tech. Discuss., https://doi.org/10.5194/amt-2018-45

Manuscript under review for journal Atmos. Meas. Tech.

Discussion started: 23 March 2018

(c) Author(s) 2018. CC BY 4.0 License.

(c) (i)
Atmospheric

Measurement

Techniques

Discussions

Table 1. Summary of Chamber Experiment Conditions.

\begin{tabular}{|c|c|c|c|c|c|c|c|c|}
\hline Precursor & \# & $\begin{array}{l}\text { VOC } \\
\text { (ppbv) }\end{array}$ & $\begin{array}{l}\mathrm{O}_{3} / \mathrm{OH}^{[1]} \\
(\mathrm{ppbv} / \mu \mathrm{L})\end{array}$ & $\mathbf{P M}\left(\mu \mathrm{g} \mathrm{m}^{-3}\right)^{[2]}$ & $\rho\left(\mathrm{g} \mathrm{cm}^{-3}\right)^{[3]}$ & f44 $(\%)^{[4]}$ & ACSM/SMPS ${ }^{[5]}$ & $\mathbf{R}^{2}$ \\
\hline \multirow{6}{*}{ isoprene } & 1 & 200 & $300 \mu \mathrm{L}$ & 140 & 1.09 & 0.057 & 2.14 & 0.99 \\
\hline & 2 & 100 & $150 \mu \mathrm{L}$ & 15 & 1.13 & 0.081 & 1.81 & 0.91 \\
\hline & 3 & 60 & $90 \mu \mathrm{L}$ & 8 & 1.26 & 0.138 & 1.40 & 0.85 \\
\hline & 4 & 80 & $120 \mu \mathrm{L}$ & 10 & 1.22 & 0.129 & 1.45 & 0.81 \\
\hline & 5 & 160 & $60 \mu \mathrm{L}$ & 22 & 1.24 & 0.160 & 1.24 & 0.96 \\
\hline & 6 & 200 & $60 \mu \mathrm{L}$ & 39 & 1.28 & 0.159 & 1.42 & 0.96 \\
\hline \multirow{4}{*}{$\alpha$-pinene } & 1 & 20 & 80 ppbv & 40 & 1.20 & 0.125 & 1.22 & 0.97 \\
\hline & 2 & 60 & $75 \mu \mathrm{L}$ & 110 & 1.26 & 0.135 & 1.44 & 0.99 \\
\hline & 3 & 10 & $80 \mathrm{ppbv}$ & 10 & 1.29 & 0.146 & 1.31 & 0.95 \\
\hline & 4 & 60 & $60 \mathrm{ppbv}$ & 11 & 1.25 & 0.152 & 1.17 & 0.88 \\
\hline \multirow{4}{*}{ toluene } & 1 & 30 & $75 \mu \mathrm{L}$ & 18 & 1.21 & 0.146 & 0.92 & 0.95 \\
\hline & 2 & 60 & $150 \mu \mathrm{L}$ & 40 & 1.35 & 0.190 & 0.79 & 0.94 \\
\hline & 3 & 30 & $50 \mu \mathrm{L}$ & 16 & 1.10 & 0.079 & 1.52 & 0.81 \\
\hline & 4 & 60 & $75 \mu \mathrm{L}$ & 11 & 1.26 & 0.129 & 1.42 & 0.99 \\
\hline
\end{tabular}

${ }^{[1]}$ The amount of $\mathrm{OH}$ is expressed as the amount of methyl nitrite $(\mu \mathrm{L})$

${ }^{[2]}$ The concentration of PM (particulate matter) is the average mass concentration of SMPS in relative stable state which have already been amended by the measured density.

${ }^{[3]} \rho$ is the average value of density after density reaches a relative steady state.

${ }^{[4]} \mathrm{f} 44$ is the average fraction of signal of $\mathrm{m} / \mathrm{z} 44$ among the total organic signal after $\mathrm{f} 44$ reaches a relatively stable value.

${ }^{[5]} \mathrm{ACSM} / \mathrm{SMPS}$ is the slope of the fitting curve. 
Atmos. Meas. Tech. Discuss., https://doi.org/10.5194/amt-2018-45

Manuscript under review for journal Atmos. Meas. Tech.

Discussion started: 23 March 2018

(c) Author(s) 2018. CC BY 4.0 License.

Table 2. Summary of Smog Chamber Experiments for CE calibration of $\left(\mathrm{NH}_{4}\right)_{2} \mathrm{SO}_{4}$ when coating with SOA.

\begin{tabular}{|c|c|c|c|c|c|c|c|c|}
\hline Precursor & \# & $\begin{array}{c}\text { VOC } \\
\text { (ppbv) }\end{array}$ & $\begin{array}{l}\mathrm{O}_{3} / \mathrm{OH}^{[1]} \\
(\mathrm{ppbv} / \mu \mathrm{L})\end{array}$ & $\begin{array}{c}\left(\mathrm{NH}_{4}\right)_{2} \mathrm{SO}_{4}{ }^{|2|} \\
\left(\mu \mathrm{g} \mathrm{m}^{-3}\right)\end{array}$ & $\begin{array}{c}\left(\mathrm{NH}_{4}\right)_{2} \mathrm{SO}_{4}{ }^{[3]} \\
\left(\mu \mathrm{g} \mathrm{m}^{-3}\right)\end{array}$ & $\begin{array}{c}\text { Org } \\
\left(\mu \mathrm{g} \mathrm{m}^{-3}\right)^{[4]}\end{array}$ & f44 & $\mathrm{CE}_{\mathrm{SOA}}{ }^{[4]}$ \\
\hline \multirow{4}{*}{$\alpha$-pinene } & 1 & 20 & $50 \mu \mathrm{L}$ & 57.5 & 66.0 & 33.5 & 0.202 & 0.333 \\
\hline & 2 & 20 & 80 ppbv & 50.3 & 56.19 & 20.1 & 0.193 & 0.324 \\
\hline & 3 & 60 & $80 \mathrm{ppbv}$ & 43.9 & 48.37 & 55.8 & 0.147 & 0.327 \\
\hline & 4 & 60 & $50 \mu \mathrm{L}$ & 40.3 & 134.24 & 303 & 0.127 & 0.966 \\
\hline \multirow{5}{*}{ toluene } & 1 & 80 & $150 \mu \mathrm{L}$ & 51.2 & 81.35 & 79.7 & 0.209 & 0.461 \\
\hline & 2 & 80 & $100 \mu \mathrm{L}$ & 55.6 & 71.0 & 25.6 & 0.237 & 0.370 \\
\hline & 3 & 100 & $50 \mu \mathrm{L}$ & 59.0 & 70.1 & 15.2 & 0.262 & 0.345 \\
\hline & 4 & 60 & $200 \mu \mathrm{L}$ & 48.3 & 57.5 & 30.7 & 0.210 & 0.345 \\
\hline & 5 & 80 & $200 \mu \mathrm{L}$ & 53.2 & 84.8 & 106.4 & 0.190 & 0.462 \\
\hline
\end{tabular}

$604{ }^{[1]}$ The amount of $\mathrm{OH}$ is expressed in terms of the amount of methyl nitrite injected $(\mu \mathrm{L})$.

$605 \quad{ }^{[2]}$ The average mass concentration of $\left(\mathrm{NH}_{4}\right)_{2} \mathrm{SO}_{4}$ seed aerosol measured by ACSM before SOA was generated.

$606{ }^{[3]}$ The average mass concentration of $\mathrm{SOA}$ coated $\left(\mathrm{NH}_{4}\right)_{2} \mathrm{SO}_{4}$ seed aerosol measured by ACSM after coated.

$607 \quad{ }^{[4]}$ The generated SOA mass concentration after it reaches relatively constant value.

$608{ }^{[5]} \mathrm{CE}$ of $\mathrm{SOA}$ coated $\left(\mathrm{NH}_{4}\right)_{2} \mathrm{SO}_{4}$. $\mathrm{CE}$ for dry, pure $\left(\mathrm{NH}_{4}\right)_{2} \mathrm{SO}_{4}$ was 0.28 in every experiment. 


\section{Figure Captions:}

610 Figure 1. Schematic of the collapsible atmospheric-pressure fluoropolymer (Teflon) smog chamber

611 and the instrument setup.

612 Figure 2. (a) A typical banana-shaped plot of aerosols generated from ozonolysis of $\alpha$-pinene; (b)

613 Time series of aerosol mass concentration measured by Q-ACSM and integrated from SMPS

614 measurements, and the corresponding $\mathrm{f} 44$ and effective density of SOA calculated from the Q-

615 ACSM and APM measurements, respectively; (c) The number size-distributions of aerosols at one

616 hour interval during the experiment.

617 Figure 3. The response factor determined from the chamber experiment by fitting the Q-ACSM

618 measured mass concentration to that deduced from SMPS-APM measurements. Only data points

619 in relative steady-state was used.

620 Figure 4. Triangle plots of (left) $\alpha$-pinene, (middle) toluene, (right) isoprene experiments. The color

621 codes represent data points in a certain experiment. $\mathrm{f} 44$ and $\mathrm{f} 43$ represent more oxidized and more

622 reduced form of organic components, respectively.

623 Figure 5. The linear correlations between Q-ACSM RFs (a) and effective density (b) with 624 respective to $\mathrm{f} 44$ obtained from all experiments. The error bars were evaluated from different data 625 points in the stable state within one experiments.

626 Figure 6. Organic, sulfate mass concentrations and $\mathrm{f} 44$ measured by Q-ACSM. Arrow 1 indicates 627 when $\left(\mathrm{NH}_{4}\right)_{2} \mathrm{SO}_{4}$ seed particles were introduced; Arrow 2 indicates when VOC precursor were 628 injected.

629 Figure 7. CE of SOA coated $\left(\mathrm{NH}_{4}\right)_{2} \mathrm{SO}_{4}$ particles. The color scale represents the Org/SO $\mathrm{SO}_{4}$ mass 630 ratio.

631 Figure 8. Overall view of SOA particle phase, effective density ( $\rho$ ), response factor(RF), relative 632 ionization efficiency(RIE) and collection efficiency(CE) variation with increasing $\mathrm{O} / \mathrm{C}$ ratio in the 633 process of SOA oxidation. 
Atmos. Meas. Tech. Discuss., https://doi.org/10.5194/amt-2018-45

Manuscript under review for journal Atmos. Meas. Tech.

Discussion started: 23 March 2018

(c) Author(s) 2018. CC BY 4.0 License.

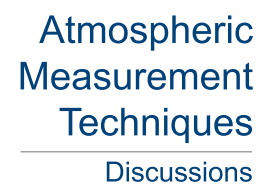

(c) (1)

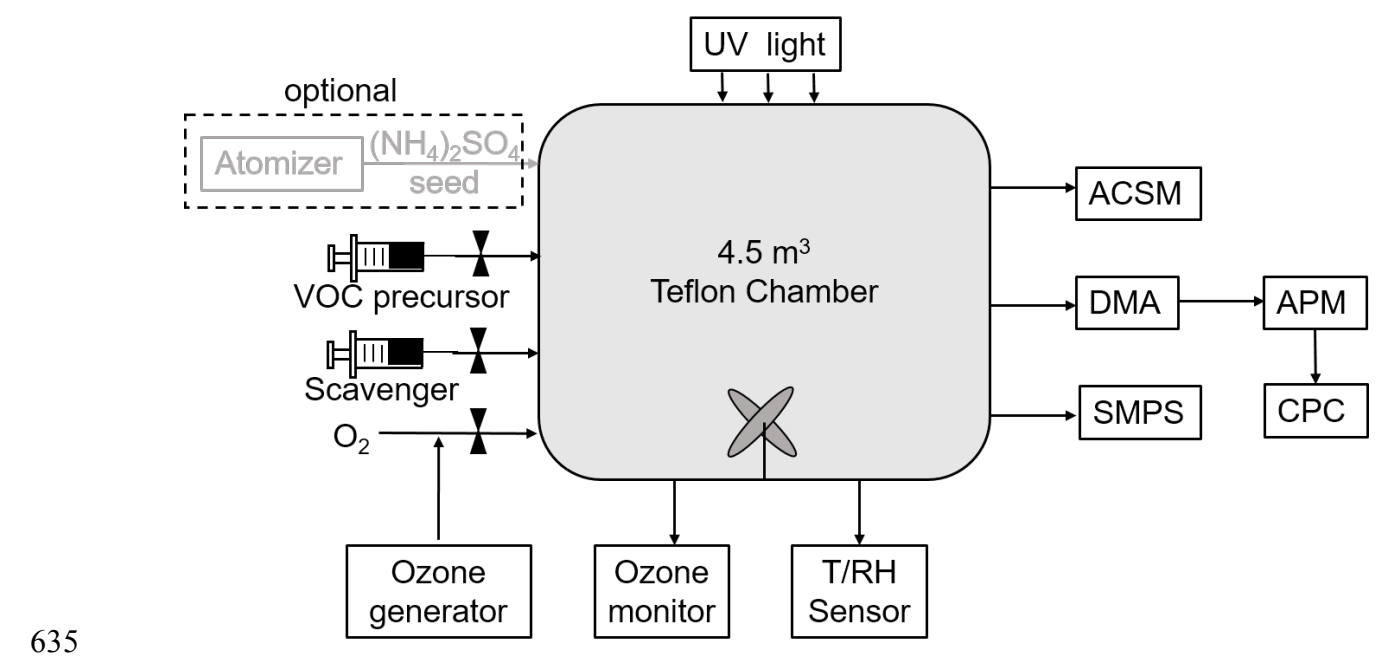

636 Figure 1. Schematic of the collapsible atmospheric-pressure fluoropolymer (Teflon) smog chamber

637 and the instrument setup.

638 
Atmos. Meas. Tech. Discuss., https://doi.org/10.5194/amt-2018-45

Manuscript under review for journal Atmos. Meas. Tech.

Discussion started: 23 March 2018

(c) Author(s) 2018. CC BY 4.0 License.
Atmospheric

Measurement

Techniques

Discussions

639
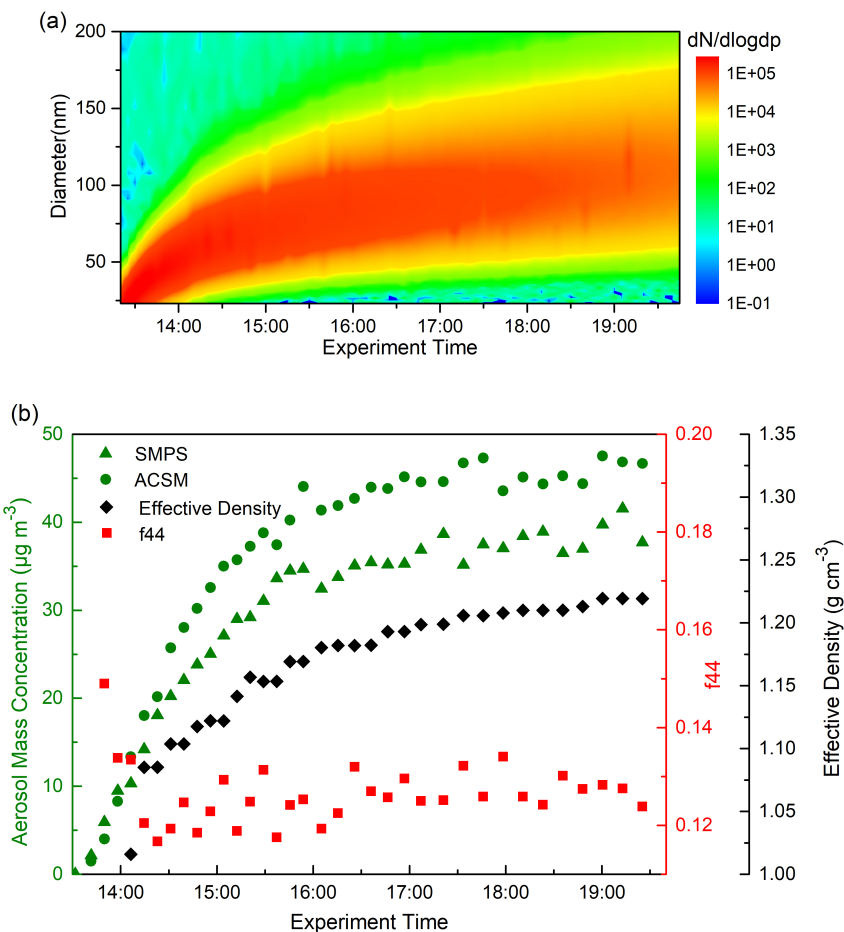

640

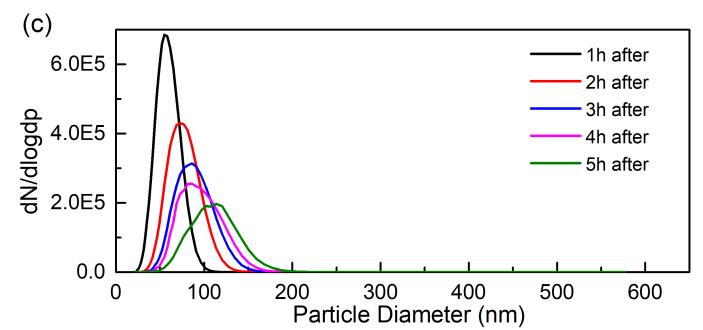

641

642 Figure 2. (a) A typical banana-shaped plot of aerosols generated from ozonolysis of $\alpha$-pinene; (b)

643 Time series of aerosol mass concentration measured by Q-ACSM and integrated from SMPS

644 measurements, and the corresponding f44 and effective density of SOA calculated from the Q-

645 ACSM and APM measurements, respectively; (c) The number size-distributions of aerosols at one

646 hour interval during the experiment.

647 
Atmos. Meas. Tech. Discuss., https://doi.org/10.5194/amt-2018-45

Manuscript under review for journal Atmos. Meas. Tech.

Discussion started: 23 March 2018

(c) Author(s) 2018. CC BY 4.0 License.

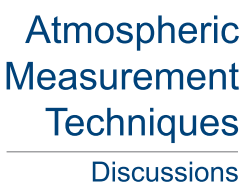

(c) (1)

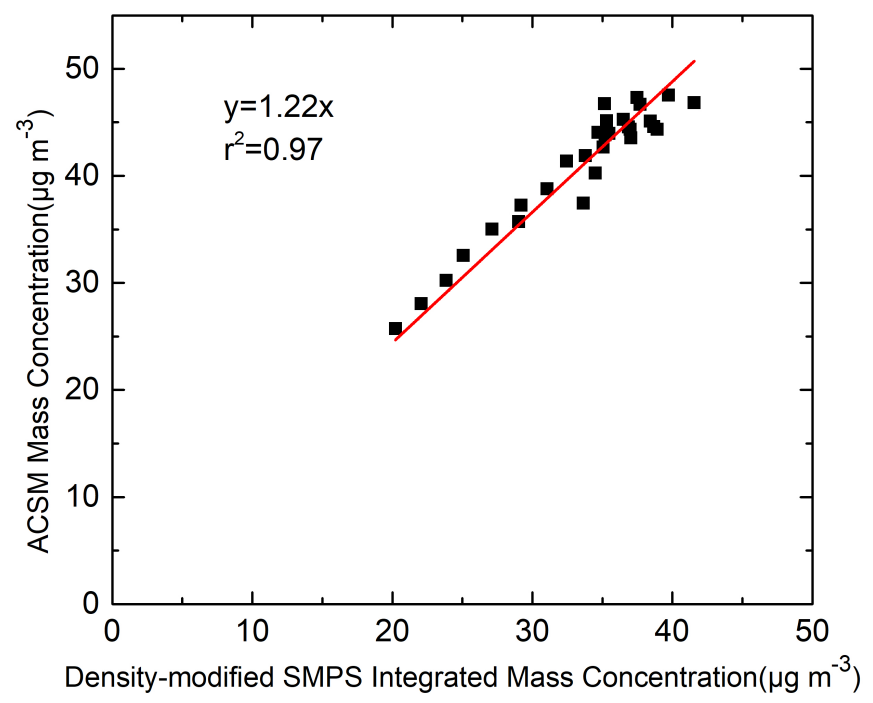

649 Figure 3. The response factor determined from the chamber experiment by fitting the Q-ACSM

650 measured mass concentration to that deduced from SMPS-APM measurements. Only data points

651 in relative steady-state was used.

652 
Atmos. Meas. Tech. Discuss., https://doi.org/10.5194/amt-2018-45

Atmospheric

Manuscript under review for journal Atmos. Meas. Tech.

Discussion started: 23 March 2018

(c) Author(s) 2018. CC BY 4.0 License.

Techniques

(c) (1)

Discussions

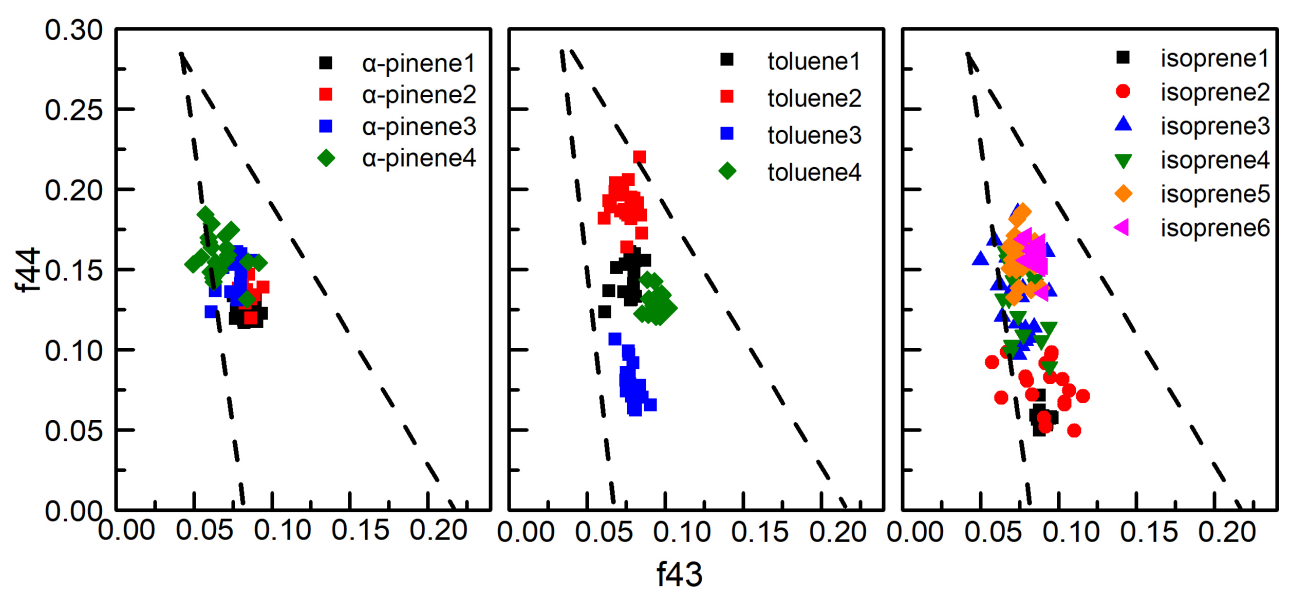

654 Figure 4. Triangle plots of (left) $\alpha$-pinene, (middle) toluene, (right) isoprene experiments. The color

655 codes represent data points in a certain experiment. f44 and f43 represent more oxidized and more

656

reduced form of organic components, respectively.

657 
Atmos. Meas. Tech. Discuss., https://doi.org/10.5194/amt-2018-45

Atmospheric

Manuscript under review for journal Atmos. Meas. Tech.

Discussion started: 23 March 2018

(c) Author(s) 2018. CC BY 4.0 License.

Techniques

(c) (1)

Discussions

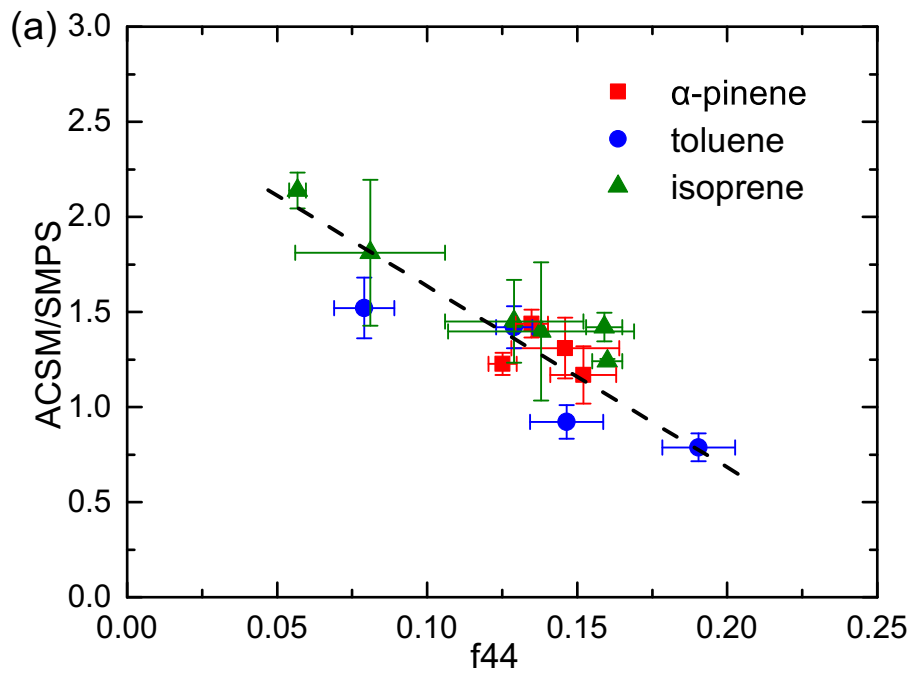

658

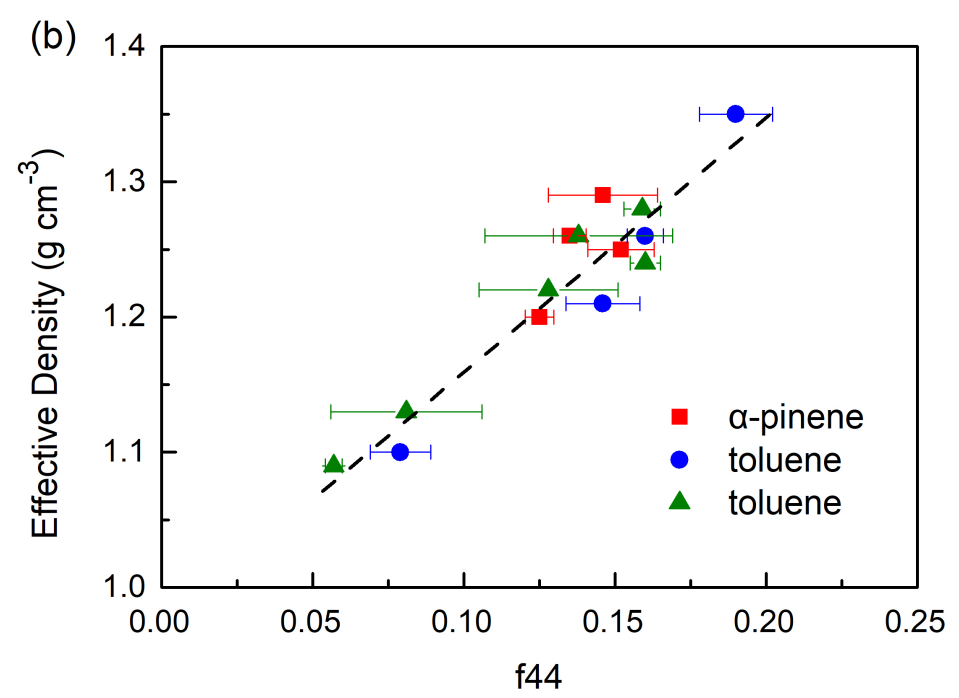

659

660 Figure 5. The linear correlations between Q-ACSM RFs (a) and effective density (b) with

661 respective to 444 obtained from all experiments. The error bars were evaluated from different data

662 points in the stable state within one experiments.

663 
Atmos. Meas. Tech. Discuss., https://doi.org/10.5194/amt-2018-45

Manuscript under review for journal Atmos. Meas. Tech.

Discussion started: 23 March 2018

(C) Author(s) 2018. CC BY 4.0 License.

(c) (i)
Atmospheric Measurement

Techniques

Discussions

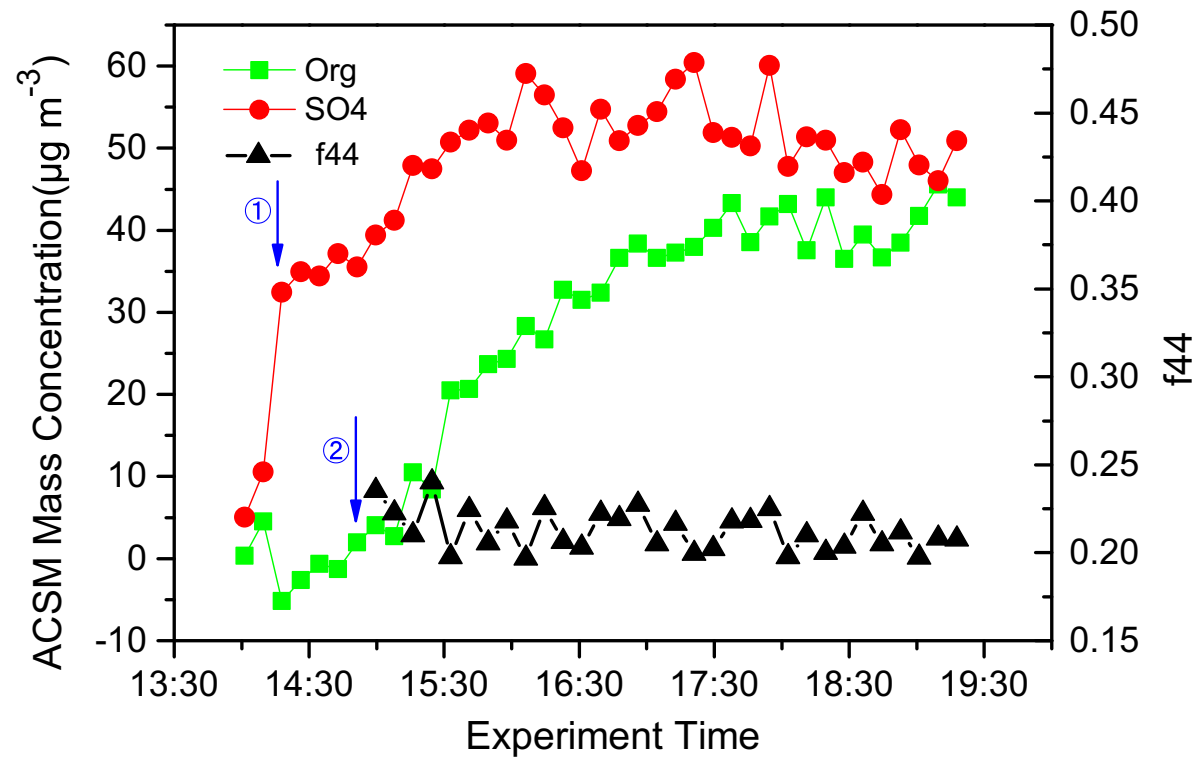

664

665 Figure 6. Organic, sulfate mass concentrations and 444 measured by Q-ACSM. Arrow 1 indicates

666 when $\left(\mathrm{NH}_{4}\right)_{2} \mathrm{SO}_{4}$ seed particles were introduced; Arrow 2 indicates when VOC precursor were 667 injected.

668 
Atmos. Meas. Tech. Discuss., https://doi.org/10.5194/amt-2018-45

Manuscript under review for journal Atmos. Meas. Tech.

Discussion started: 23 March 2018

(C) Author(s) 2018. CC BY 4.0 License.

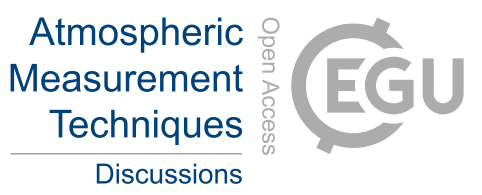

669

670 Figure 7. CE of SOA coated $\left(\mathrm{NH}_{4}\right)_{2} \mathrm{SO}_{4}$ particles. The color scale represents the Org/SO $\mathrm{SO}_{4}$ mass

671 ratio.

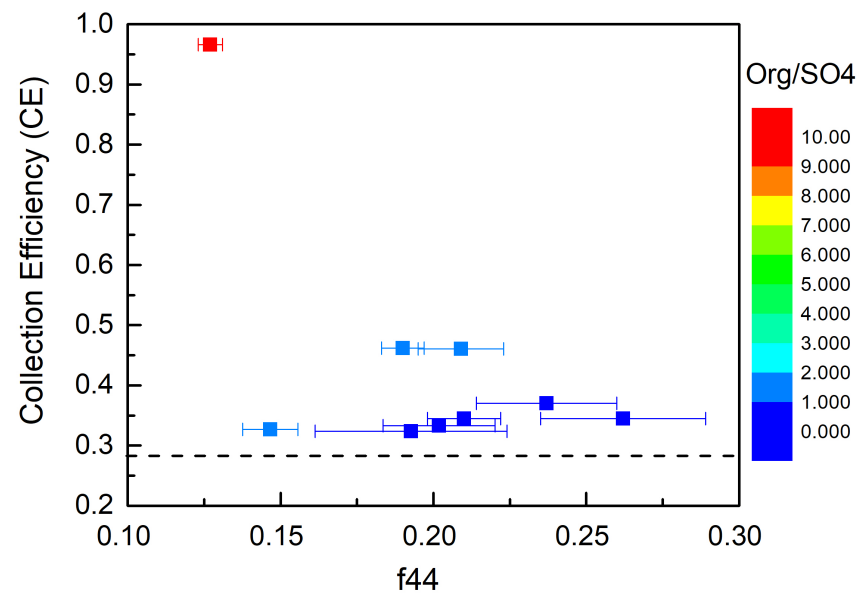

672 
Atmos. Meas. Tech. Discuss., https://doi.org/10.5194/amt-2018-45

Manuscript under review for journal Atmos. Meas. Tech.

Discussion started: 23 March 2018

(c) Author(s) 2018. CC BY 4.0 License.

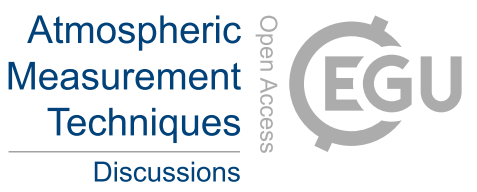

(c) (1)

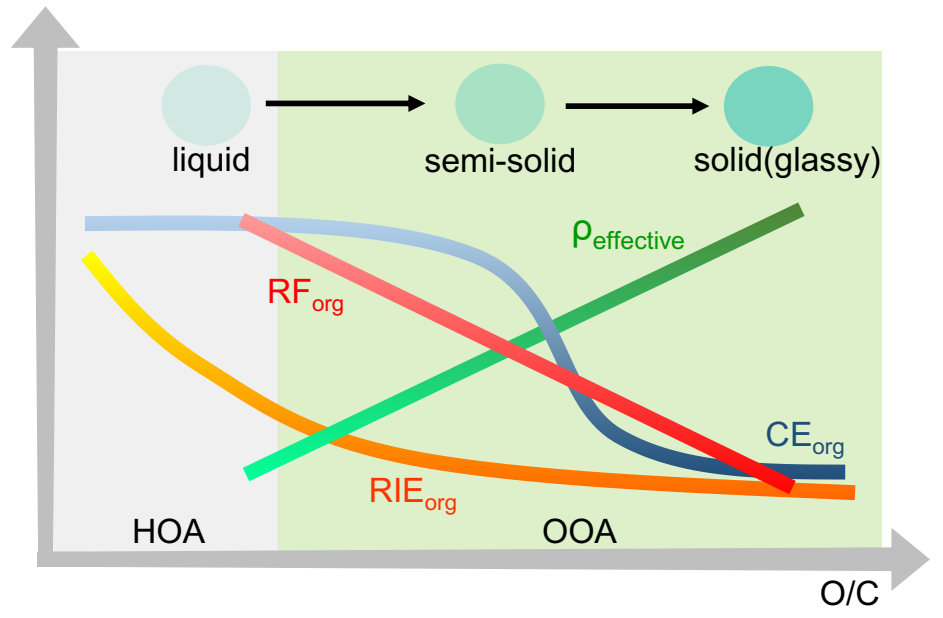

674 Figure 8. Overall view of SOA particle phase, effective density ( $\rho)$, response factor(RF), relative

675 ionization efficiency(RIE) and collection efficiency(CE) variation with increasing $\mathrm{O} / \mathrm{C}$ ratio in the 676 process of SOA oxidation. 